International Statistical Congress, held at Berlin, decided "That the care of preparing and putting into execution the regulations to be followed in the construction of the standards, and of the system itself, should be entrusted to an International Commission, which will also see to the correction of the small scientific defects of the system." The International Geodesical Conference held at Berlin in I 867 decided: "In order to define the common unit of measures for all the countries of Europe, and for all times, with as much exactness as possible, the Conference recommends the construction of a new prototype European Metre. The length of this European Metre should differ as little as possible from that of the Metre of the Archives in Paris, and should in all cases be compared with the greatest exactness. In the construction of the new prototype standard, care should be taken to secure the facility and exactness of the necessary comparisons." And "the construction of the new prototype metre, as well as the preparation of the copies destined for different countries, should be confided to an International Commission, in which the States interested should be represented." Since then, the Imperial Academy of Science of St. Petersburg has taken the matter in hand, and a committee of the Physico-Mathematical class, consisting of MM. Struve, Wild, and Jacobi, has made a report on the subject, observing that the standard metric weights and measures of the various countries of Europe and of the United States differ by sensible though small quantities from one another. They expressed their opinion that the continuation of these errors would be highly prejudicial to science. They believed that the injurious effects could not be guarded against by private labour, however meritorious, and they recommended that an International Commission should be appointed by the countries interested to deal with the matter. This suggestion was approved by the French Government, and consequently the Conference will take place in Paris in August next, when the Astronomer Royal, Professor William H. Miller, and the Warden of the Standards, will represent this country. Everything seems thus tending towards the early realisation of the great scheme of uniformity of weights and measures throughout the world.

\section{MUSEUMS OF NATURAL HISTORY}

THERE is no doubt of the popularity of museums of natural history with the lower classes. That it is otherwise with more educated people is perhaps attributable, not so much to indifference to scientific knowledge, as to the fact that hardly any scientific knowledge is to be gained by a cursory inspection of crowded collections, arranged with reference to economy of space rather than to the existing conditions of zoological science. It must not be forgotten that the sentiment of mere wonder, which the stranger forms of animal life are so calculated to excite, was satisfied, or at least blunted, in early childhood, in the case of those of us who have had access to well-illustrated books, and to the zoological gardens of great cities.

Twenty years hence it will hardly be credited that in the year 1869 a competent naturalist, after visiting fifty of the principal museums of Europe, reported on them in the following terms :- "So far as his observations ex- tended, he found no museum where any other purpose than a desire to produce a pleasing and convenient disposition of the specimens was manifested in the general plan of arrangement. In the few cases where there was an evident intention of showing some of the more important general features connected with the distribution of life over the face of the globe, or in the successive geological formations, the imperfection of the means has been too great to afford any great restit. Among the fifty museums visited, not one was found in a building especially designed for the purpose of exhibiting collections arranged to show the history of life."* We may fairly hope that the condition of things above described will not endure much longer. The ever-widening interest in the higher problems of zoology awakened by the writings of Darwin and his followers, will no doubt, in time, move even the conservative professors and curators of the great European museums to urge upon their Governments the necessity of providing them with the means of making the collections under their charge visible embodiments of what is now known of the history, distribution, and affinities of animal life, instead of simple gatherings of curiosities, or at best mere storehouses of materials for the professed naturalist. The rearrangement of the great national collections in properly constructed buildings would, even under the "most favourable circumstances, be a work of years, and one entailing great and irksome labour upon the distinguished officers of these museums. Meanwhile, there is every prospect that the hopes we have expressed in reference to the European collections will be almost immediately realised in the case of the great museum of Harvard College, under the charge of one of the most eminent of living zoologists, Professor Louis Agassiz. Thanks to the liberality of the State Legislature of Massachusetts, a sum of 75,000 dollars, payable in three annual instalments, is available for this great work, conditionally upon the raising by subscription of like sums. We are glad to learn from the trustees that the first 25,000 dollars have been subscribed, and the corresponding 25,000 dollars received from the State. The spirit which is animating Prof. Agassiz in this matter will be best gathered from his own words in the official report now before us. After paying due tribute to those who, by bringing together the great collections of the old world, laid the foundations of our present knowledge, he says: "We have no longer the right to build museums after this fashion. ... If I mistake not, the great object of our museums should be to exhibit the whole animal kingdom as a manifestation of the Supreme Intellect. Scientific investigation in our day should be inspired by a purpose as animating to the general sympathy as was the religious zeal which built the cathedral of Cologne or the basilica of St. Peter's. The time is past when men expressed their deepest convictions by these wonderful and beautiful religious edifices; but it is my hope to see, with the progress of intellectual culture, a structure arise among us which may be a temple of the revelations written on the material universe" (p. 6). Prof. Agassiz is able to write in the following encouraging terms of the immediate prospects of his great undertaking:-" With the prospect for

* These words are to be found at p. $4 \mathrm{r}$ of a paper entitled, "Annual Report of the Trustees of the Museum of Comparative Zoology at Harvard College, Cambridge, together with the Report of the Director, 1868." Boston: 1869. 
the next three ycars of an income large enough to secure the aid of competent assistants in the different departments, we shall be able to put our immense collections in complete order, and to enlarge the building sufficiently to exhibit all our specimens in their true relations. I hope that in three years any intelligent observer will be able to say that a mere walk through our museum teaches him something of the geographical distribution of animals, of their history in past ages, of the laws controlling their growths as they now exist, and of their mutual affnitiesin short, that the whole will be so combined as to illustrate all that science has thus far deciphered of the plan of creation. This is ray hope, and it is shared by the efficient corps of assistants on whose co-operation 1 largely depend for its fulfilment (p. 4)." Prof. Agassiz has set himself a noble task, and we doubt not that when it is completed, the museum of Harvard College will be an intellectual monument worthy alike of its curator and of the science of which he is so distinguished an ornament.

\section{OUTLINES OF HUMAN PHYSIOLOGY}

Gmundriss der Physiologie des Menschen. Von Prof. Dr.

L. Hermann. Dritte gänzlich umgearbeitete Auflage. r870. (Berlin: Hirschwald. London: Williams and Norgate.)

W

HEN this work first appeared, now more than seven years ago, it at once became our favourite handbook of physiology, and it has ever since been our constant companion. Perhaps the chief reason why it so especially commended itself to us was the fact that it served as the clearest and best exponent of what may be called the radical school of physiology. Its general arrangement differed altogether from that of most modern text-books. It entirely threw on one side that division into "functions" (function of respiration, function of digestion, and the like) which, after all, does not lessen much the labour of the author, and certainly leads the student astray, throwing, as it does, into the background, or even completely hiding, the essential oneness and solidarity of the animal body, and bringing the learner to regard the organism as a bundle of "functions," one of which might easily be pulled away without much harm being done. The leading idea of the book was to follow out as closely as possible the doctrine of the conservation of energy. That idea was kept steadily in view throughout the volume, and faithfully adhered to.

Another remarkable feature was the bold attitude taken up towards recent discoveries. These are always great stumbling-blocks to teachers and text-books. Some authors, especially German authors, put in everything that comes up, leaving time and future editions to take out again the things that wither up. Others, again, put in nothing that does not seem to be already fairly established, and the student who trusts to these alone has perhaps to wait several years, till a new edition tells him of results which have had, it may be, a most powerful infitence on the progress of the science for as many years back. A third class, and of these Prof. Hermann is one, make up their mind as to what they think will stand and what will not, and so accept the one and reject the other, though both may have been published yester- day. This course being bold is of necessity dangerous; and a new edition is, in the case of such books, a most critical occasion.

An unusual popularity has now brought the present work to a third edition, and the author may certainly congratulate himself on the little which he has had to undo Many new things which in $186_{3}$ he boldly accepted have since been ratified by general consent.

The present edition differs from the preceding two in being made much larger and more complete. We trust that it has now reached its full growth, for one of the great merits of the first edition was its small size. Otherwise, beyond the increased filling up of all parts, the book does not differ materially from what it was. We are glad to see that several oversights, such, for instance, as the extraordinary statement of the first edition that the apex of the heart beats between the seventh and eighth ribs, have been corrected, and that the author gives a fair account of matters in reference to which he has been engaged in personal controversies, as, for example, in the physiology of muscle.

The boldness in selection of material to which we have referred, renders the book in some measure unsuitable for a student not sufficiently advanced to have acquired a physiological judgment ; but we would urge it upon the notice of all who wish to have a clear and succinct exposition of the physiology of the present day.

M. F.

\section{OUR BOOK SHELF}

On the Strength of Beams, Columns, and Arches. By B. Baker, Assoc. Inst. C.E. (London: E. and F. N. Spon, 1870 .)

THE subject matter of this little volume is of great importance to Civil Engineers. All structures resolve themselves ultimately into beams, columns, and arches, of some kind. It is therefore of great importance that the engineer should be familiar with the mode of ascertaining their strength or their resistance. We approve, in the main, of Mr. Baker's endeavour to dispense with high mathematics by substituting geometrical solutions for ordinary problems, because, unfortunately, mathematics is not the strong side of English engineers, although England has produced the greatest of mathematicians. But the author seems to labour under serious misapprehensions. He proposes his geometrical solutions, because he thinks that the use of mathematics "involves an unjustifiable waste of time, with the great contingent disadvantage that it checks the growth of sound judgment in the engineer, by giving a fictitious appearance of accuracy to his results which are not susceptible of exact deduction." This is a grievous error. The spirit of mathematics is the expression of most acute and refined reasoning ; and how can the practice of intellectual reasoning check the growth of sound judgment in the engineer? The fictitious appearance of accuracy above mentioned, is altogether beside the question, because it is optional; but not so the correctness of our reasoning and arguments. The author makes the above statement in his preface, and we find, unfortunately, that throughout the volume the spirit of mathematics is sadly offended. Let us take for example the author's mode of calculating the strength of beams. He shows us how the strength of a beam may be found geometrically, and derives the formulæ for rectangular and other beams, assuming the neutral axis of the beam to pass through the centre of gravity of the sectional area of the beam. 